\title{
THE ANALYSIS OF LITHUANIAN PAYMENT MARKET: ARE WE STUCK TO CASH?
}

\section{Rita Remeikiene $^{1}$, Ligita Gaspareniene ${ }^{2}$, Gintare Grigaliune ${ }^{3}$}

\author{
${ }^{1,2,3}$ Department of Banking and Investment, Mykolas Romeris University, Ateities str. 20, Vilnius, Lithuania \\ E-mails: ${ }^{1}$ rita.remeikiene@mruni.eu (corresponding author); ${ }^{2}$ ligitagaspareniene@mruni.eu; \\ 3.grigaliune@gmail.com
}

\begin{abstract}
Rapid technologic advancement alongside with increasing individual needs determine popularity of information technologies. As a result, a number of newly-developed instruments that enable to make payments in the methods different from cash are introduced to consumers in the payment market. The aim of this article is to establish how widely cash is used for making payments in Lithuanian payment market. The results of the research have revealed that the number of cash settlements in Lithuanian payment market is decreasing. Although the number of newly issued debit and credit cards is increasing, cash remains the prevalent method of payment, which corresponds to the trends of payment in the EU payment market.
\end{abstract}

Keywords: cash, non-cash settlements, payments, payment market, payment methods, Lithuania.

JEL Classification: D14; D53; G21.

\section{Introduction}

Rapid process of globalisation alongside with social and economic development as well as evolving international relations promote increasing flows of goods, services and money transfers. Both physical and juridical entities (i.e. households and business enterprises) are looking forward to having efficient and convenient payment tools that would enable to make and accept different forms of payments. Unconstrained, safe and qualitative functioning of payment making processes calls for the development of easily accessible and reliable payment systems. In addition, it is extremely important to perceive the role of payment systems in daily settlements and comprehend the principles of the main payment processes while making necessary transactions.

Since 2016, Lithuanian Bank Systems (banks, credit unions, payment and e-money institutions) that meet the requirements of the Single European Payment Area (SEPA) are invited to join this area. The innovations in the single payment system are expected to make preconditions for the effusion of non-cash payments in comparison to the scopes of cash payments. Nevertheless, the statistical data (Abdou, Ghosh 2011; Lundberg et al. 2014) shows that cash payments still prevail in the European payment market. For this reason, it is purposeful to research how widely cash is used for making settlements in the payment markets of particular countries. The research on this issue would reveal the preferences of customers in the payment market and could contribute to the development of the measures directed towards promotion of noncash payments.

Previous scientific research on the topic of cash payments basically covers the studies on evaluation of contractors' satisfaction with cash payment terms (Odeyinka, Kaka 2005; Gallery et al. 2008; Carmichael, Balatbat 2010; Chen 2012; Tran, Carmichael 2012, 2013), peculiarities of cash-in-hand culture (Williams, Windebank 2004; Williams et al. 2012; Smith 2014), the impact of cash holdings on investment-cash flow sensitivity (Kim 2014), modelling of payment mechanisms in the construction of a supply chain (Farris II, Hutchinson 2002; Randal, Farris II 2009; Motawa, Kaka 2009) and modification of cash conversion cycle (Talonpoika et al. 2014). Nevertheless, the aspects of entities' attachment to one or another method of payment, in particular cash, has hardly been researched in detail. More comprehensive studies on the topic of cash usage include the analysis of the evolution of the methods of payment (Worthington, Edwards 2000; Dube, Glascock 2006), cash transaction convenience in the payment stage (Lundberg et al. 2014), cash flow forecasting (Linares-Mustaros et al. 2013), the motives to pay in cash versus other forms of payment (Abdou, Ghosh 2011) and consumer preferences for payment methods (Lawson, Todd 2003). However, the peculiarities of cash usage within different segments of the payment market have not been disclosed. 
The aim of this article is to establish how widely cash is used for making payments in Lithuanian payment market. In order to fulfil the defined aim, the following objectives have been raised: 1) to analyse the peculiarities of the payment market; 2) to select and introduce the methodology of the research; 3 ) to review the statistical data on the volumes of payments made in cash and non-cash in Lithuanian payment market; 4) to compare the trends of payment types in the EU and Lithuanian payment markets. The methods of the research include systematic and comparative analysis of the scientific literature and statistical data review.

\section{Peculiarities of the payment market: theoretical background}

\subsection{The role of a payment system in the overall finance market}

According to European Central Bank (2010), a payment system is the key component of the overall finance market. It combines the finance market infrastructure, securities and derivatives. With reference to Bikas and Novickyte (2008), a payment system refers to a method that is used for monetary settlements or clearing, i.e. non-monetary settlement for goods, services and/or securities. It ensures flows of funds in financial markets by the requirements of commercial and/or financial transactions. Global payment system is often referred to as an International Fund Transfer System (IFTS) (European Central Bank 2010). European Central Bank (2010) distinguishes the following structural parts of the global payment system:

- Payment instruments - the tools of payment authorisation and completion (e.g. the tools by which payers authorise their bank funds and give a permission to transfer these funds).

- Processes, including clearing - the actions that allow to transfer funds between banks and accounts.

- Bank agreement tools - legal commitments between banks. For instance, if a payer's bank is obliged to compensate a particular amount of funds to a remittent's bank, the services provided by a third party, i.e. a payment/settlement agent, can be engaged.

Payment (financial) institutions that provide customers (physical, juridical entities and public institutions) with payment services and tools, as well as organisations that manage payment, clearing and transfer accounts are considered as the key agents operating in a payment system.
Financial institutions have to ensure a sufficient quantity of cash in all the areas of consumer service. In the last decade, they focus on cash management optimisation which allows to improve the process of financial service provision and reduce cash management costs.

Summarising, it can be stated that any payment system is a set of instruments, intermediaries, rules, procedures, processes and interbank fund transfers that enables to manage money turnover in a country or within the boundaries of currency circulation. A reliable and convenient payment system ensures the efficient functioning of the overall payment market.

\subsection{The features of the payment market}

Over the last decades, the markets of transfers, settlements and financial instruments are becoming increasingly important in both global and individual economics. This trend has mostly been determined by the obvious increase in the number and value of financial transactions as well as by rapid advancement of financial innovations, communication and IT.

Proper management of cash demand is one of the main aims of any financial institution. According to Norkus (2013), cash composes a substantial share in money supply, and the scopes of cash usage must be considered while making monetary policies since cash determines governmental revenues earned from money issuance (seignorage). The variance of the volumes of cash payments in comparison to the volumes of non-cash payments (i.e. payments made by checks, credit or debit cards, cryptographic currencies) is always considered by monetary policy institutions since cash payments strongly influence the revenues of the central banks earned from seignorage.

The trend of the reduction in the volumes of cash payments can be observed almost in each developed country, but the degree of each country's involvement in this process is rather different. The key reason that determines a shrinking share of cash payments in the overall payment system is the spread of alternative and more convenient methods of non-cash payment (credit or debit cards, cryptocurrencies). The overall payment market is dealing with the increasing number of non-cash transactions which is soaring due to global economic development and GDP growth as well as lower values of cash payments determined by advancement of remote payment methods.

The other feature of the modern payment market is price convergence and decline, observed 
in the global markets, especially in the EU. The processes of globalisation determine market convergence and price assimilation. It is expected that in the future prices of goods and services in global markets will continue to assimilate, which will lead to extremely intensive competition. As a result, businesses will be forced to manage their payment processes with highest efficiency.

Summarising, it can be stated that the basic features of the modern payment market are reduction of the volumes of cash payments and increasing number of non-cash payments. Globally observed trends of price convergence and decline are expected to reduce the number of cash payments even further due the necessity for business companies to retain their competitive advantage by efficient management of payment processes.

\section{Substantiation of the research methodology}

The analysis of accumulated knowledge on a particular topic (in this case - the analysis of Lithuanian payment market) requires systematic review and classification of the relevant scientific literature. The method of scientific literature analysis was selected for the research as it enables to concentrate on the topic and accommodates several data collection techniques such as literature review, library research and historical analysis. In addition, it enables to combine the results of both theoretical and empirical research obtained in previous scientific studies and surveys. Finally, the key benefit of scientific literature analysis is its contribution to disclosure of descriptive inferences that would be missed in typical statistical analyses.

In this research, systematic analysis of the scientific literature review allowed to disclose the peculiarities of the payment market, identify the determinants of cash and bank card usage, to accumulate the statistical data on the volumes of payments made in cash and by cards by Lithuanian population. The method of comparative analysis enabled to compare Lithuanian statistics with the one in the EU.

In order to conduct this research, several databases with the large number of scientific journals on economics, engineering and finance management were searched. The target search enabled to collect a substantial proportion of the material on the peculiarities of the payment market within various studies.

The research was performed in the following stages: 1) after the comprehensive analysis of the scientific literature, the boundaries of the researched problem were identified; 2) the role of a payment system in the overall finance market was described, and the features of the payment market were identified; 3) new aspects of the research were found, i.e. it was disclosed whether Lithuanian population are stuck to cash while making their daily settlements.

Further in the research, the statistical data on the volumes of payments made in cash and noncash in Lithuanian payment market has been reviewed, and the comparative analysis of the trends of payment types in the EU and Lithuanian payment markets has been conducted.

\section{The review of the volumes of payments in cash and non-cash in Lithuanian payment market}

Lithuania, as an independent state, has been going through a comparatively short period of economic development. Hence, its economy is still developing and moving towards the level of advanced economies. Since the country regained its independence and started transferring from planned to market economy not sooner than 25 years ago, its economy is considered to be young and growing. Due to this reason, Lithuanian population is rather conservative and inclined to select payments in cash because they look psychologically safer. Such trends have prevailed for a long period of time. However, the recent years have brought some radical changes in Lithuanian payment market. In order to establish the changes in population's habits in terms of the payment methods preferred, The Bank of Lithuania has conducted annual surveys during the period of 2012-2015 (see Fig. 1).

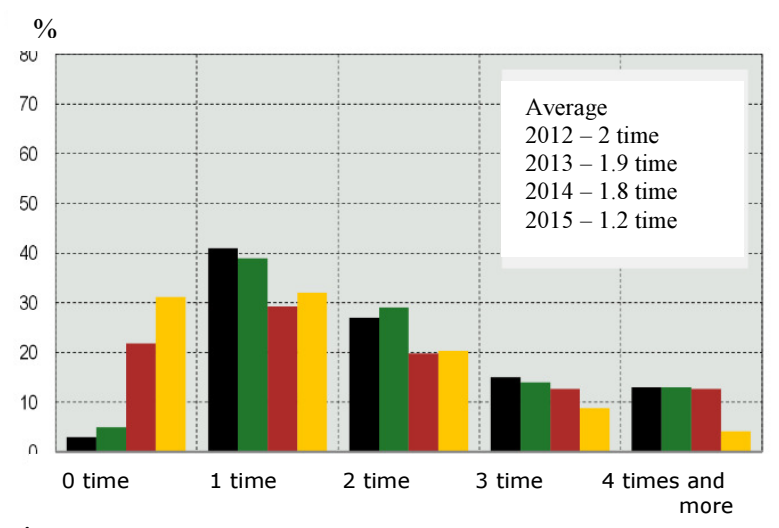

Fig. 1. The trequency of cash payments on a day before the day of the survey (Source: The Bank of Lithuania 2015: 8)

As it can be seen from Figure 1, the number of payments in cash significantly decreased during the researched period, i.e. it feel by 0.8 times in 2015 in comparison to 2012. The results of the 
survey show that the impact of cash on daily settlements is gradually decreasing - Lithuanian population starts giving preferences to the usage of smart equipment and the Internet; what is more, the number of customers who pay by cards for low value goods or services is also rising. The results reveal that cash is still an extremely important method of payment in Lithuania. However, the substantial changes in population's habits can be observed. Having considered pros and cons of noncash payments, Lithuanian people are more and more frequently doing without cash.

The quantities of cash kept in households are predicted to decrease in the future. This trend is considered to emerge due to the reason that commercial banks operating in the territory of the Republic of Lithuania charge higher fees for money cashing starting from July 9, 2015. In addition, the Parliament of Lithuania is tightening the terms for cash payments. All these measures should lead to more intensive usage of electronic bank cards and lower circulation of cash in daily settlements.

Commercial banks operating in the territory of the Republic of Lithuania have also changed the quotas of free money withdrawal. Henceforth, 0.4 percent fee is charged for withdrawal of the amount of cash that exceeds the limit of 500 EUR per month. This, undoubtedly, will promote more intensive usage of both e-banking services and bank cards. At present, Lithuania is one of the EU member-states, where the largest share (nearly 80 percent) of the overall settlements is conducted in cash, while Scandinavian countries, i.e. the countries of origin of the majority of commercial banks that operate in the territory of the Republic of Lithuania, cash settlements compose only 40 percent of the overall settlements. Hence, although the Government of the Republic of Lithuania criticize the Bank for Lithuania for not taking any efficient measures against commercial banks and their wish to raise the tariffs for money cashing, in this case commercial banks act rather reasonably. The intensions of some commercial banks to apply lower bank card management tariffs in exchange for higher money cashing tariffs (the tariffs for bank card management are expected to drop from 5.5 EUR to 4.8 EUR per year) should also contribute to smaller number of cash settlements in Lithuania.

In the sector of shadow economy, settlements in any other forms (e.g. bank cards or transfers) apart from cash are not practiced. Cash is a prevalent method of payment in this sector considering the fact that usage of bank cards can easily be detected, and identities of a transfer parties can be identified. Due to this reason, the Parliament of the
Republic of Lithuania took another significant step leading towards reduction of the number of cash payments in trade and finance markets. It is considered that the maximum amount of a transaction for particular products or services between physical entities might not exceed the limit of 5 thousand EUR. If one of the parties of a transaction is a juridical entity, then such transaction might not exceed the limit of 3 thousand EUR. Transactions that exceed the defined limits, must be conducted in electronic space. This way, it is not difficult to observe revenues and expenditure of both physical and juridical entities. Hence, it should serve as an efficient measure not only to reduce cash flows in the market, but also to partially decrease the scopes of shadow economy (Zakevicius 2015).

With reference to statistical data (Zakevicius 2015), Lithuanian commercial banks are losing their influence by both the scopes of cash payments and electronic transfers. What is more, the banks are losing their positions to specialised payment institutions. Over the second quarter of the last year, the total amount of cash transfers amounted to 13 billion EUR; 11.2 billion EUR out of this amount were transferred by payment institutions, whereas commercial banks transferred only 1.9 billion EUR out of the total amount. In comparison to the year before, commercial banks lost a substantial share of the payment market, which dropped from 19.7 percent to 14.6 percent. At the same time, specialised payment institutions were able not only to retain, but also to raise their share in the payment market, which grew from 79.6 to 84.8 percent (Norkus 2013).

The Bank of Lithuania puts effort into assurance of transparency and competitiveness in the payment market. For this reason, it publically announces variant bank tariffs. If such practice will be followed in the future, variance (in particular, increase) of bank tariffs will discourage customers from bank service usage and will push them to choose alternative methods of payment.

The number and value of cash payments made for the products and services acquired by households is also decreasing as well as the total amount of cash expenditure. In 2015, the number of population possessing bank cards increased, despite the fact that a substantial share of debit and credit card holders do not have a habit to actively use bank cards for daily settlements in trade or service provision locations, as it was revealed by the population survey conducted by the Bank of Lithuania (2015). The survey also disclosed that the number of the respondents who possess a debit card increased by 5 percent in 2015, and composed 87 
percent of the total number of respondents who possess a bank account. However, possession of a debit card does not ensure cards usage for making of settlements - 58 percent of the respondent who possess a debit card did not use it for settlements the day before the survey. The respondents admitted treating cash as a safer and more convenient method of payments. Considering the statistical data explicated above, it can be stated that Lithuanian payment market shows a great potential for debit and credit card usage for the completion of daily settlements. To accelerate the changes in this field, the measures that would enable to change entities' (in particular, households and individual payers) attitudes towards the safety and convenience of non-cash payments should be developed.

Following the data presented by Lithuanian credit institutions (The Bank of Lithuania 2015), over the year (during the third quarter of 2014 in comparison to the same quarter of 2015), the number of card readers in trade and service provision locations in Lithuania jumped up to 45 thousand units. Nevertheless, inhabitant still appoint the lack of opportunities to make payments by cards. Following the data of the survey (The Bank of Lithuania, 2015), the largest part of card holders observed the lack of card reading equipment in markets and trade fairs (41 percent of the respondents), beauty and cosmetics salons (21 percent of the respondents), health service institutions (16 percent of the respondents), kiosks, small country shops and postal departments (14 percent of the respondents). Hence, it can be concluded that the number of the locations where customers can get access to card reading equipment has to be enlarged because this would contribute to the fulfilment of customers' needs and would allow to raise the overall demand for products and services. What is more, the regulation of the EU on interbank tariffs which came into force last year ensures favourable preconditions to traders and service providers to reduce card acceptance fees and implement card reading equipment in their operation areas.

Alongside with the rise of the number of debit cards possessed by physical entities, the opposite trends can be observed in the sector of credit cards. With reference to the data of the survey (The Bank of Lithuania, 2015), the number of the customers who expressed the wish to have such card issued substantially decreased over the year: in 2014, it amounted to 23 percent of the total number of account owners, while in 2015 it dropped to 14 percent of the total number of account owners.

Over the period of 2014-2015, the number of the residents who received their income in cash dropped by one third: in 2015, it amounted to 29 percent of the total number of account owners. 40 percent of the total number of account owners received their wages transferred directly their accounts and were entitled to lower service tariffs applied by credit institutions.

31 percent of the respondents admitted not paying for anything in cash on the day before the survey's day in 2015. In 2014, the number of such people composed 22 percent. On average, in 2014 frequency of payments in cash per day for a person made 1.8 times, while in 2015 it dropped to 1.2 times, which confirms reduction in the frequency of cash payments. In addition, over the researched period, the median of cash payments dropped from 9.6 to 7.2 EUR.

With reference to the results of the survey (The Bank of Lithuania 2015), 80 percent of Lithuanian population had an account in at least one credit institution. 67 percent of the respondents appointed using bank services, and 43 percent of respondents appointed using the services of other credit institutions. The share of credit union money and electronic money users respectively amounted to 3 and 5 percent in 2015 .

The survey (The Bank of Lithuania 2015) also revealed that the pricing applied by Lithuanian credit institutions is always or sometimes hard to understand to two thirds of the respondents who have accounts in these institutions. A significant part (41 percent) of the respondents who have accounts in Lithuanian credit institutions appointed that fixed monthly fee charged for a payment service basket would be more acceptable to them than the fees charged for each payment service or operation. Fee system based on a payment service basket would be selected by 33 percent of the respondents who have accounts in Lithuanian credit institutions.

Although the number of cash payments is decreasing, they still dominate while making settlements for utilities. Even having accounts in Lithuanian credit institutions, a large part of Lithuanian population (42 percent of the respondents) paid for utilities in cash a month before the survey month. Internet transfers for this purpose were conducted by 35 percent of the respondents, while the service of direct debit was engaged by 21 percent of the survey participants.

The number of Lithuanian residents who receive their earnings (wages, retirement benefits, royalties) in cash decreased during the researched period: in 2015, 29 percent of the survey participants received their earnings in cash, when in 2014 this percentage composed 42 percent. However, 
the majority of the residents who receive earnings in credit institution accounts cashed their earnings: in 2015, 67 percent of the respondents appointed that withdrawal of money from their accounts is the basic source of their cash. In comparison to 2014 , the number of such respondents increased by 18 percent. In 2015, 14 percent of the survey participants admitted taking cash from other physical entities, while in 2014, 24 percent of the respondents confirmed doing so. Also, in 2015, 0.6 percent of the respondents did not use cash (in 2014, 0.2 percent of the respondents indicated not using cash).

In comparison to 2014, in 2015 Lithuanian residents used smaller amounts of cash for daily settlements. The number of daily settlements in cash also declined: 31 percent of the respondents stated that they did not use cash for the settlements on the day before the survey in 2015 , i.e. the number of the respondents who did not use cash for the settlements on the day before the survey increased by 9 percentage points in 2015 in comparison to 2014. The other respondents also conducted a smaller number of settlements on the day before the survey: the share of the respondents who completed only one payment increased by 3 percentage points in 2015 in comparison to 2014; the share of the respondents who completed two payments remained unchanged; finally, the share of the respondents who completed three or four payments on the day before the survey respectively decreased by 4 and 9 percentage points in 2015 in comparison to the same data in 2014. An average frequency of cash payments per day per person made 1.2 times in 2015, while in 2014 it amounted to 1.8 times. What is more, in 2015 , the share of the respondents whose cash payment amounts varied in the interval from 1 to 10 EUR deceased by 3 percentage points, i.e. to 25 percent; the share of the respondents whose cash payment amounts varied in the interval from 11 to 20 EUR remained unchanged; finally, the share of the respondents whose cash payment amounts exceeded 20 EUR decreased by one third, i.e. to 20 percent, in comparison to the same data in 2014. The median of cash payment amount decreased from 9.6 to 7.2 EUR during the researched period.

The survey also revealed that Lithuanian residents are more inclined to pay in cash in trade locations rather than make cash settlements with other physical entities. However, what concerns the payments made on a random day before the day of the survey, it was established that cash usage declined in both segments of the payment market. In 2015, 37 percent of the respondents did not complete any cash payments on the day before the day of the survey, i.e. the number of such respondents grew by 10 percentage points in 2015 in comparison to the same data in 2014. 76 percent of the respondents did not make any cash settlements with other physical entities in 2015, the number being by 8 percentage points higher in comparison to 2014. In 2015, 23 percent of the respondents spent cash amounts varying in the interval from 1 to 10 EUR in trade locations on the day before the day of the survey (in 2014, this number composed 28 percent); 14 percent of the respondents admitted having spent cash amounts that exceeded 20 EUR in trade locations on the day before the day of the survey. 16 percent of the survey participants paid from 1 to 10 EUR to other physical entities in 2015 (in 2014, this number amounted to 17 percent), while only 3 percent of the survey participants admitted having paid more than 20 EUR to other physical entities in the same year (in 2014, the number amounted to 6 percent of the respondents).

The share of Lithuanian residents who have at least one payment card increased during the researched period, but a substantial number of the respondents refused to use their credit cards and stuck only to the usage of debit cards. At least one card (commonly - a debit card) was possessed by 92 percent of the respondents who had accounts in Lithuanian credit institutions in 2015 (in 2014, the number of such respondents made 89 percent). The share of the residents who possess a debit card increased by 5 percentage points during the researched period. The number of credit card holders significantly decreased - from 23 to 14 percent respectively in 2014 and 2015. The number of digital card holders dropped by 3 percentage points over the researched period.

It was established that the biggest part of Lithuanian population do not use their payment cards for daily settlements. Over the researched period, 58 percent of the respondents - payment card holders - did not use their payment cards for making daily settlements on the day before the day of the survey. 66 percent of the payment card holders made their payments in cash on the day before the day of the survey. The share of the respondents who used their payment cards for daily settlements on the day before the day of the survey grew by 4 percentage points over the researched period, and amounted to 42 percent of the survey participants in 2015. Nevertheless, 66 percent of the respondents admitted paying in cash on the day before the day of the survey.

In 2015, the largest share of the respondents payment card holders - appointed that they would occasionally use their payment cards while paying 
for low-value purchases, while payment cards would actively be used to pay for high-value purchases. In 2015, vast majority of the respondents appointed that would choose cash to pay for the purchases with value lower than 15 EUR.

80 percent of the respondents would choose cash to pay for the purchases with the value lower than 3 EUR, and 65 percent of the respondents would pay in cash for the purchases with the value between 3 and 15 EUR. 69 percent of the respondents appointed that they would pay by payment card for the purchases with the value higher than 60 EUR. In comparison to 2014, the number of the respondents who would always (independently of the value of a purchase) pay by card decreased by 13 percentage points, i.e. from 46 percent in 2014 to 33 percent in 2015.

Summarising, the research has revealed that the number of cash settlements in Lithuanian payment market is gradually decreasing. Although the number of newly issued debit and credit cards is increasing, cash remains the prevalent method of payment, especially while paying for low-value products and services in trade and service provision locations.

\section{The comparative analysis of the trends of payment types in the $E U$ and Lithuanian payment markets}

Every year, the European Parking Association (EPA) estimates the turnover of European parking industry by employing the method of payment cards. It is interesting to note that the indicators of advanced countries are comparatively low in this respect, which could serve as a significant indicator showing that cash remains a predominant method of payment even in these countries (see Table 1).

The data, presented in Table 1, reveals that card usage as a percentage from the overall number of transactions was extremely low in Italy ( 8 percent of the overall transactions) and Germany (12 percent of the overall transactions), while Sweden, the UK and Denmark showed the highest rates (6065 percent of the overall transactions) of card usage. In addition, there is some evidence showing that card usage rate reflects the overall parking tax rate in these countries, i.e. lower taxes determine more intensive cash flows. EBC survey disclosed that card usage rate in the EU was gradually growing over the period of 2012-2015 (EPA 2015). For instance, card usage for parking payments in Spain increased from 4.4 to 56 percent over the researched period, while in the UK it grew from 9.5 to 60 percent.
Table 1. Review of the statistics on payment card usage for parking in the EU in 2012 (Source: EPA 2015)

\begin{tabular}{l|c|c|c}
\hline Member state & $\begin{array}{c}\text { Number of } \\
\text { payment } \\
\text { cards } \\
\text { issued } \\
\text { per capita }\end{array}$ & $\begin{array}{c}\text { Number of } \\
\text { card trans- } \\
\text { actions } \\
\text { per capita }\end{array}$ & $\begin{array}{c}\text { Average } \\
\text { value of } \\
\text { card transac- } \\
\text { tion per } \\
\text { card, EUR }\end{array}$ \\
\hline Finland & 1.45 & 204 & 34 \\
\hline Sweden & 2.15 & 185 & 36 \\
\hline Denmark & 1.36 & 181 & 45 \\
\hline United Kingdom & 2.35 & 157 & 59 \\
\hline Estonia & 1.33 & 148 & 16 \\
\hline Netherlands & 1.82 & 146 & 40 \\
\hline Luxemburg & 3.27 & 124 & 74 \\
\hline France & 1.27 & 121 & 50 \\
\hline Portugal & 1.89 & 117 & 45 \\
\hline Belgium & 1.82 & 106 & 55 \\
\hline Ireland & 1.32 & 75 & 70 \\
\hline $\begin{array}{l}\text { Euro Zone } \\
\text { average }\end{array}$ & $\mathbf{1 . 4 2}$ & $\mathbf{6 5}$ & $\mathbf{5 2}$ \\
\hline Slovenia & 1.60 & 58 & 37 \\
\hline Latvia & 1.13 & 51 & 20 \\
\hline Spain & 1.50 & 48 & 44 \\
\hline Cyprus & 1.52 & 43 & 83 \\
\hline Austria & 1.31 & 39 & 50 \\
\hline Germany & 1.60 & 37 & 63 \\
\hline Lithuania & 1.21 & 34 & 18 \\
\hline Malta & 1.74 & 33 & 74 \\
\hline Italy & 1.11 & 29 & 82 \\
\hline Poland & 0.84 & 27 & 25 \\
\hline Czech Republic & 0.93 & 25 & 41 \\
\hline Hungary & 0.89 & 24 & 46 \\
\hline Slovakia & 0.98 & 21 & 37 \\
\hline Greece & 1.22 & 6 & 84 \\
\hline Romania & 0.63 & 6 & 37 \\
\hline Tulgaria & 1.07 & 4 & 48 \\
\hline & $\mathbf{1 . 4 4}$ & $\mathbf{7 2}$ & $\mathbf{5 2}$ \\
\hline
\end{tabular}

The analysis of the total number of transactions in Lithuania revealed that over the period of 2012-2014, it grew from 227.77 million EUR in 2010 to 362.3 million in 2014 (see Fig. 2).

The data, presented in Figure 2, discloses that the overall number of transactions in Lithuanian payment market shows the trends of increase, which can also be observed in the EU payment market.

As it can be seen from Figure 3, credit transfers predominated in Lithuanian payment market in respect of other types of payment over the period of 2010-2014. Strong positions were also taken by direct debits, while cheques and e-money transactions are not popular with the participants of Lithuanian payment market. 


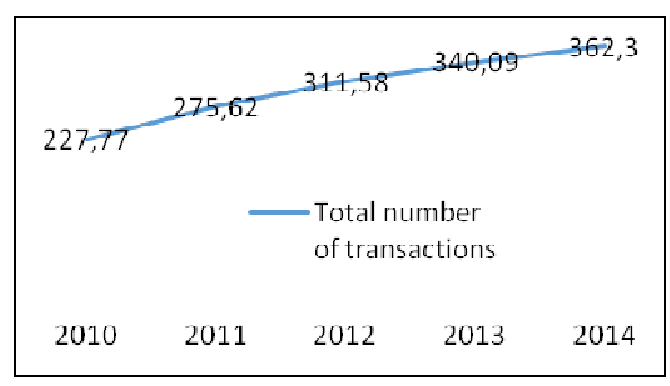

Fig. 2. The total number of transactions in Lithuanian payment market over the period of 2012-2014, mln. EUR (Source: compiled by the authors with reference to the data of European Central Bank Payment Statistics 2015)

The dynamics of the number of transactions per type of payment service in Lithuanian payment market over the same period has been depicted in Figure 3.

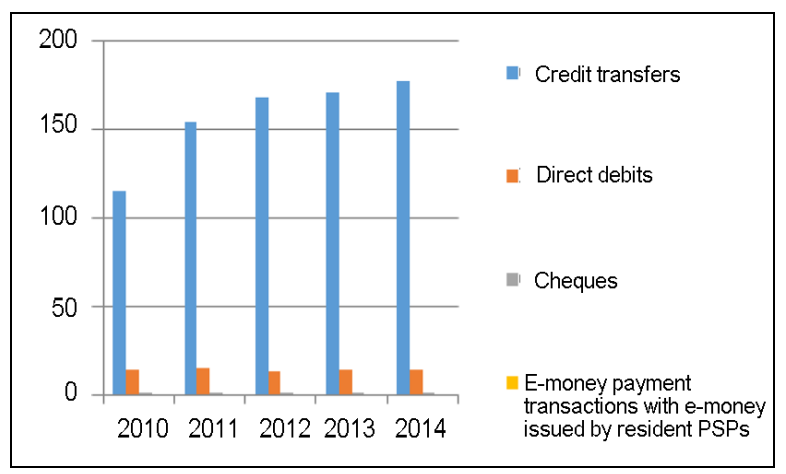

Fig. 3. The number of transactions per type of payment service in Lithuania during 2010-2014 period (Source compiled by the authors with reference to the data of

European Central Bank Payment Statistics 2015)

Summarising, it can be stated that the main determinants of payment card usage are availability, open-mindedness and reliance (Goczek, Witkowski 2016). Considering the findings of previous studies, which propose that prevalence of a particular type of payment is determined by customers' habits and culture in the finance markets, it can be stated that transfer from cash to non-cash payments can be accelerated by developing the measures that would enable to change entities' (in particular, households' and individual payers') attitudes towards the safety and convenience of noncash payments.

\section{Conclusions}

With reference to the research results, the following conclusions can be made:

1. Any payment system is a set of instruments, intermediaries, rules, procedures, processes and interbank fund transfers that enables to manage money turnover in a country or within the boundaries of currency circulation. A reliable and convenient payment system ensures the efficient functioning of the overall payment market.

2. The basic features of the modern payment market are reduction of the volumes of cash payments and increasing number of non-cash payments. Globally observed trends of price convergence and decline are expected to reduce the number of cash payments even further due the necessity for business companies to retain their competitive advantage by efficient management of payment processes.

3. The results of the research have revealed that the number of cash settlements in Lithuanian payment market is decreasing. Although the number of newly issued debit and credit cards is increasing, cash remains the prevalent method of payment, which corresponds to the trends of payment in the EU payment market.

4. The number of transactions in Lithuanian payment market shows the trends of increase as well as in the EU payment market. However, cash remains a predominant method of payment even in advanced countries as well as in Lithuanian payment market.

Finally, the results of the research propose that transfer from cash to non-cash payments in Lithuanian payment market can be accelerated by developing the measures that would enable to change entities' (in particular, households' and individual payers') attitudes towards the safety and convenience of non-cash payments.

\section{Disclosure statement}

The authors declare that they do not have any competing financial, professional, or personal interests from other parties.

\section{References}

Abdou, K.; Ghosh, S. 2011. What motivates REITs to pay cash versus other forms of payment in mergers and acquisitions, Journal of Property Investment \& Finance 29(1): 19-34. http://dx.doi.org/10.1108/14635781111100173

Bikas, E.; Novickyte, L. 2008. Mokejjimo sistema Litas: dabartis ir perspektyva, Ekonomika 82: 7-30.

Carmichael, D. G.; Balatbat, M. C. A. 2010. A contractors' analysis of the likelihood of payment of claims, Journal of Financial Management of Property and Construction 15(2): 102-117. http://dx.doi.org/10.1108/13664381011063412 
Chen, H. L. 2012. Empirical behavioural analysis of project contractors' supply-chain payment terms, Supply Chain Management: an International Journal 17(3): 277-289.

http://dx.doi.org/10.1108/13598541211227117

Dube, S.; Glascock, J. L. 2006. Effects of the method of payment and the mode of acquisition on performance and risk metrics, International Journal of Managerial Finance 2(3): 176-195. http://dx.doi.org/10.1108/17439130610676466

European Central Bank. 2010. The payment system: payments, securities and derivatives, and the role of the Eurosystem [online], [cited 16 March 2016]. Available from Internet:

https://www.ecb.europa.eu/pub/pdf/other/payment system201009en.pdf

European Central Bank. 2015. Payment statistics for 2014 [online], [cited 11 February 2016]. Available from Internet:

https:/www.ecb.europa.eu/press/pdf/pis/pis2014.e n.pdf?d9feb0268bb38b960b806ea69b6bf467

Farris II, M. T.; Hutchinson, P. D. 2002. Cash-to-cash: the new supply chain management metric, International Journal of Physical Distribution \& Logistics Management 32(4): 288-298.

http://dx.doi.org/10.1108/09600030210430651

Gallery, G.; Gallery, N.; Supranowicz, M. 2008. Cashbased related party transactions in new economy firms, Accounting Research Journal 21(2): 147166. http://dx.doi.org/10.1108/10309610810905935

Goczek, L., Witkowski, B. 2016. Determinants of card payments, Applied Economics 48(16): 1530-1543. http://dx.doi.org/10.1080/00036846.2015.1102846

Kim, T. N. 2014. The impact of cash holdings and external financing on investment-cash flow sensitivity, Review of Accounting and Finance 13(3): 251273. http://dx.doi.org/10.1108/RAF-09-2012-0080

Lawson, R.; Todd, D. 2003. Consumer preferences for payment methods: a segmentation analysis, International Journal of Bank Marketing 21(2): 72-79.

Linares-Mustaros, S.; Ferrer-Comalat, J. C.; CassuSerra, E. 2013. The assessment of cash flow forecasting, Kybernetes 42(5): 720-735.

http://dx.doi.org/10.1108/K-03-2013-0060

Lundberg, H.; Ohman, P.; Sjodin, U. 2014. Transaction convenience in the payment stage: the retailers' perspective, Managing Service Quality 24(5): 434454. http://dx.doi.org/10.1108/MSQ-02-2014-0032

Motawa, I.; Kaka, A. 2009. Modelling payment mechanisms for supply chain in construction, Construction and Architectural Management 16(4): 325 336. http://dx.doi.org/10.1108/09699980910970824

Norkus, Z. 2013. Kodèl tarpukario Lietuva neteko Vilniaus, o dabartinè - atsiliko nuo Estijos, Politologija 2(70): 1-61.

Odeyinka, H. A.; Kaka, A. 2005. An evaluation of contractors' satisfaction with payment terms influencing construction cash flow, Journal of Financial
Management of Property and Construction 10(3): 171-180.

http://dx.doi.org/10.1108/13664380580001074

Randall, W. S.; Farris II, M. T. 2009. Supply chain financing: using cash-to-cash variables to strengthen the supply chain, International Journal of Physical Distribution \& Logistics Management 39(8): 669689. http://dx.doi.org/10.1108/09600030910996314

Smith, G. C. C. 2014. After a market panic: cash is king, Managerial Finance 40(5): 506-534. http://dx.doi.org/10.1108/MF-07-2013-0166

Talonpoika, A. M., Monto, S.; Pirttila, M.; Karri, T. 2014. Modifying the cash conversion cycle: revealing concealed advanced payments, International Journal of Productivity and Performance Management 63(3): 341-353.

http://dx.doi.org/10.1108/IJPPM-12-2012-0130

The Bank of Lithuania. 2015. Lietuvos gyventoju apklausos dèl mokejjimo ipročiu apžvalga [online], [cited 11 Februaray 2016 ]. LB. Available from Internet: http://www.lb.lt/lietuvos_gyventoju mokejimo_iprociu_apklausos_apzvalga_2015_m

The European Parking Association (EPA). 2015. European parking industry payments landscape [online], [cited 10 January 2016]. CMS Media. Available from Internet:

http://www.europeanparking.eu/cms/Media/Europ ean_Parking_Industry_Payments_Landscape_Draf t_for_Consultation_23092015.pdf

Tran, H.; Carmichael, D. G. 2012. The likelihood of subcontractor payment: Downstream progression via the owner and contractor, Journal of Financial Management of Property and Construction 17(2): $135-152$. http://dx.doi.org/10.1108/13664381211246589

Tran, H.; Carmichael, D. G. 2013. A contractor's classification of owner payment practices, Engineering, Construction and Architectural Management 20(1): 29-45.

http://dx.doi.org/10.1108/09699981311288664

Williams, C. C.; Nadin, S.; Windebank, J. 2012. How much for cash? Tackling the cash-in-hand culture in the European property and construction sector, Journal of Financial Management of Property and Construction 17(2): 123-134. http://dx.doi.org/10.1108/13664381211246570

Williams, C. C.; Windebank, J. 2004. The heterogeneity of cash-in hand work, International Journal of Sociology and Social Policy 24(1/2): 124-139.

Worthington, S.; Edwards, V. 2000. Changes in payment markets, past, present and future: a comparison between Australia and the UK, International Journal of Bank Marketing 18(5): 212-221. http://dx.doi.org/10.1108/02652320010356771

Zakevicius, G. 2015. Kiek kainuoja grynieji pinigai Lietuvoje?, Review of the State News [online], [cited 05 March 2016]. Available from Internet: http://apzvalga.eu/kiek-kainuoja-grynieji-pinigailietuvoje.html 